AL-TA'LIM JOURNAL, 25 (3), 2018, (272-280)

(Print ISSN 1410-7546 Online ISSN 2355-7893)

Available online at http://journal.tarbiyahiainib.ac.id/index.php/attalim

\title{
Analysis on Relational-Understanding in Solving Problem for Field Independent Students
}

Received: $07^{\text {th }}$ July 2018; Revised: $04^{\text {th }}$ September 2018; Accepted: $26^{\text {th }}$ November 2018

Permalink/DOI: http://dx.doi.org/10.15548/jt.v25i3.502

Nok Izatul Yazidah *)

Institut Keguruan dan Ilmu Pendidikan

Budi Utomo Malang, Indonesia

E-mail: izatulyazidah@gmail.com

\section{Dian Fitri Argarini}

Institut Keguruan dan Ilmu Pendidikan

Budi Utomo Malang, Indonesia

E-mail: kejora.subuh14@gmail.com

\section{Yunis Sulistyorini}

Institut Keguruan dan Ilmu Pendidikan Budi Utomo Malang, Indonesia

E-mail: yunis.sulistyorini@gmail.com

\begin{abstract}
The purpose of this study is to describe students' relational understanding in solving problems for FI students. The subjects of this research are Senior High School students having field independent cognitive style in Malang and chosen randomly. The subjects consist of two students. Sheet of GEFT test, sheet of Combinatorial questions, and interview sheet were used in this study. The finding of the study showed that mediumacademic achievement student had an ability on relational understanding as the same as the high-academic achievement student. Meanwhile, the process in solving problem made by the high-academic achievement student was likely similar to the accurate process in solving problems.
\end{abstract}

\section{*) Corresponding Author}

Keywords: Relational understanding, problem solving, field independent.

How to Cite: Yazidah, N., Argarini, D., \& Sulistyorini, Y. (2018). Analysis on Relational-Understanding in Solving Problem for Field Independent Students. Al-Ta Lim Journal, 25(3). doi:http://dx.doi.org/10.15548/jt.v25i3.502

\section{INTRODUCTION}

Students think that learning mathematics requires a high level intelligence, but actually the requirements are understanding and skill (Geary, 2004; Jordan \& Levine, 2009; Morgan, Farkas, \& $\mathrm{Wu}, 2009)$. Understanding is a technical term used in mathematics learning. Indonesia (2005); Nasional (2006); Pendidikan (2007) stated that the objectives of mathematics learning in Senior High School include : (1) understanding the concept of mathematics, explaining the relationship among the concepts and allocating the concept or algorithm, flexibly,accurately, efficiently and precisely in solving the problems; (2) using logical reason on pattern and style, doing mathematics manipulation on creating generalization, arranging proof, or explaining mathematics ideas and statements; (3) solving problems that cover the ability to understand problems, design mathematics model, finishing the model and interpreting the solution of the problems; (4) communicating ideas with symbols, tables, diagrams, or other media to clarify the conditions or problems; and (5) having a good appreciation on mathematics usage in life, those are having curiosity, attention and interest in learning mathematics, having perseverance and confidence in solving problem (Hebert, 2001; Surya \& Syahputra, 2017). This means that in learning mathematics 
students are required to have an understanding ability and to discover their own knowledge. Teachers should only act as facilitator. Moreover, Friel et al. (2001); Graham (2001) stated that mathematics in school has a vision, learning with understanding.

According to Draper (2002); Ferrini-Mundy (2000); Stylianides \& Stylianides (2007) understanding can be categorized, parted, and elaborated into a number of components to form a deeper view about student's thinking process. Furthermore, Suherman (2003) stated that understanding is an adequate definition about something, more than memorizing, enables the students to catch the meaning or main idea and explains it by using their previous knowledge.

Skemp (2006) has differentiated understanding into three kinds, those are: (a) instrumental understanding someone's ability using mathematic procedure to solve the problem without knowing the reason of using that procedure. In the other words, students only know "how" not "why", (b) relational understanding someone's ability using mathematic procedure with the full of awareness of "how" and "why" such kind of procedure is used, and (c) logical understanding an understanding closely related with convincing him/herself and persuading others.

Relational understanding is important in mathematics learning. Student who has a good relational understanding does not only remember and memorize a concept, but also knows how and why something happened so that he or she can use it to finish any problems dealing with daily life. Relational understanding has a higher level than instrumental understanding (Amato, 2004; Barmby, Harries, Higgins, \& Suggate, 2007; Boaler, 2008). The process of developing student's relational understanding can be perceived by connecting the mathematical concepts to the representation of images, symbols or words (Anwar, Yuwono, \& As' ari, 2016). Problem solving is one of steps that can be taken to develop a students' relational understanding.

This study focused on field independent (FI) students based on academic achievement. FI students were chosen for having unique characteristics. Individuals with an independent field cognitive style have characteristics such as ability to analyse to separate objects from their environment, ability to organize objects, impersonal orientation, and individual professions, defining their own goals, and prioritizing intrinsic motivation and internal strengthening (Knuth, Alibali, McNeil, Weinberg, \& Stephens, 2005; McNeil et al., 2006; Sahin, Yenmez, \& Erbas, 2015). Students with FI cognitive styles tend to have a high degree of independence in looking at a stimulus without dependence on teachers and cognitive style of FD that tend to and rely heavily on educational resources from educators (Lusiana, 2017).

The result of observation and interview that has been done with mathematics teachers in Senior High School showed that in solving any storyformed questions especially on Combinatorial material, students lacked of ability. Students often finished the questions only on what the teacher has asked without knowing how the further solution was. In this case teachers thought that students had less ability to understand the given questions and tended to be lazy to finish that story-formed questions. In addition, students' focus was only on combinatorial formula that they have gained from their teacher rather than a deeper thinking when they met such questions. Based on the above explanation, the statement of problem in this research is how relational understanding in solving problems for FI students based on academic achievement is. Whereas the aim of this research is to describe a relational 
understanding in solving problems for FI students.

\section{METHOD}

The subject of this research was senior high school students having field independent cognitive style in Malang that have been randomly chosen. The subject consisted of two students, a mediumacademic achievement student and a highacademic achievement student. The medium-academic achievement student was initiated by $\mathrm{S} 1$, and for the highacademic achievement student it was initiated by $\mathrm{S} 2$. Instruments required included a sheet of GEFT test, a problem solving test, and interview guidance. A GEFT test was intended to determine student whit FI cognitive style. A problem solving test was about Combinatorial. The questions were related with census rules in determining numbers of licensed plate so that the number on that plate was formed in the even number. Interview guidance consisted of main questions to gain further relational understanding in solving problem about combinatorikca. This research is a descriptive qualitative research. The analysis of the qualitative data referred to (Creswell \& Creswell, 2017) that consisted of (1) processing and preparing the data to be analyzed, (2) reading the entire data, (3) coding the data and applying it to describe the data that will be analyzed, (4) interpreting the description of the analyzed data.

\section{RESULTS AND DISCUSSIONS}

This research aimed to describe a relational understanding in solving problem for FI cognitive students seen from the academic achievement differentiation. The problems given to the students was related with combinatorica namely the implementation of the rules of multiplication concept in daily life. A question is a problem if a question is challenging to be completed or answered, and there are non-routine procedures to solve the problems (Widjajanti, 2009). The detail problems are given as follow: Car licensed plate in Malang region begins with the alphabet $N$, followed by four numbers and ended by two alphabets. How many car plates are formed if the four numbers are an even number and there are not the same numbers?"

The detail solving stages of combinatorica problems in this research referred to the Polya problems solving as served as follows. The stages of problems solving included understanding the problem, making a plan, applying a plan and reviewing (Ayllón, Gómez, \& Ballesta-Claver, 2016). The reviewing stage was rejected in this research. The stage of understanding the problems is explained below. It is known that car's licenced plate consists of three parts: the first part in the form of an alphabet, the second part containing 4 numbers, and the third containing two alphabets. The problem is in relation to the arrangement of the plate which numbers form an even number with different number. The designing stage determined that to solve this problems it could use the multiplication rules by making four boxes filled with numbers and two boxes filled with alphabets.

The designing stage is explained as follows. Based on the known licensed plated, it can be illustrated below:

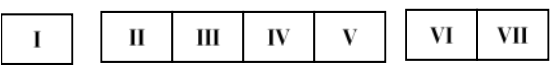

Figure 1 Solution of problem

The first part is a box that can only be filled with alphabet "N". The second part is four boxes that can be filled with 4 different numbers by following the rule that the fifth box should be filled first because this box is the last digit of the even number that will be made. To make the licensed plate with even numbers, the last box should be filled with $0,2,4,6$ or 8. 
The filling of this second part is divided into two choices, those are the fifth box is filled with " 0 " or filled with another even numbers except " 0 ". If the fifth box is filled with " 0 ", it means this box only has one choice, " 0 ". Then, the second box has 9 choices; those are numbers except " 0 ". The third box has 8 choices; those are numbers that have not been put in the fifth and the second box. The fourth box has 7 choices; those are numbers that have not been filled in the second, the third and the fifth box.

\begin{tabular}{|l|l|l|l|}
\hline 9 & 8 & 7 & 1 \\
\hline
\end{tabular}

Figure 2 Solution of Case 1

If the fifth box is filled with another number except " 0 ", it has 4 choices; those are number $2,4,6$, or 8 . Then the second box has 8 choices by numbers that have not been put in the fifth box and number " 0 ". The third box also has 8 choices by numbers that is not in the second and fifth box. The fourth box could be filled with 7 choices by the numbers not put in the box 2,3 , and 5 .

\begin{tabular}{|l|l|l|l|}
\hline 8 & 8 & 7 & 4 \\
\hline
\end{tabular}

Figure 3 Solution of Case 2

It can be concluded that the second part consists of choices. Each box in the third part has 26 choices because the alphabet can be the same so that this part has $26 \times 26=676$ choices. Based on the multiplication rules, the lisenced plates that can be formed are $1 \times 2.296 \times 676=1.552 .096$ choices.

\section{Description of relational understanding in solving problems of $\mathrm{S} 1$}

S1 student in this research was represented as a student with mediumacademic achievement. At the stage of understanding problems, SI knew that there were 4 columns for numbers and 2 alphabet columns from the licensed plate.
The problems that should be solved were arranging four numbers so that it could be licensed plates with different even numbers. However, at the planning stage S1only made 4 empty boxes and filled them with multiplication rules. So, though S1 has not really understood what she has known because she only focused on the number part of the licensed plate without paying attention to the alphabet part, S1 could determine the precise census rule to solve the problem based on what she knew and what was being asked.

At the stage of conducting plan, S1 made 4 empty boxes and filled them as follows:

\begin{tabular}{|l|l|l|l|}
\hline 9 & 8 & 7 & 5 \\
\hline
\end{tabular}

Figure 4. S1's solution

There were 5 choices of numbers in the fourth box that formed even number; those are 0,2, 4, 6 and 8. The first box had 9 choices because from 10 chosen numbers it has been taken one as the fourth box. The second and the third box' choices were less one by one because the number should be different. So, there would be $9 \times 8 \times 7 \times 5=2520$ choices of licensed plate that could be made. It revealed that S1 did not enclose the alphabet part to arrange the plate. It could be stated that $\mathrm{S} 1$ has not been able to change the problem of licensed plate as the expected illustration. Student could determine the even numbers used to determine the former of even number so that $\mathrm{S} 1$ was able to correlate the concept of even number definition. Students were able to determine which box that should be filled first, that was the first box-not the fourth one. Moreover, student only focused on the one by one subtraction on the first, the second and the third box because the numbers should not be the same so that it can be stated that S1 has not been able to determine the numbers that could be set in each box. 


\section{Description of relational understanding in solving problems of $\mathrm{S} 2$}

S2 student in this research was represented as a student with highacademic achievement. At the stage of understanding problems, S2 knew that there were 4 columns for numbers and 2 columns for alphabet in the licensed plate. The problems that should be solved were in the arrangement of four numbers so that it could be licensed plates with different even numbers. However, at the planning stage S2 only made 4 empty boxes and filled them with multiplication rules. So, though S2 has not really understood what he has known because he only focused on the number part of the licensed plate without paying attention to the alphabet part. Nevertheless, S2 could determine the precise census rule to solve the problem based on what he knew and what was being asked.

At the stage of conducting plan, S2 made 4 empty boxes and filled them as follows. S2 made four empty boxes to arrange the even numbers. The first case was that the fourth box was filled with number " 0 " only. There was a choice for the fourth box, which was number " 0 ". For the first box, there were 9 choices available. Because the number might not be repeated, so the choices were less one for the next box. The second box had 8 choices. For the third box, there were 7 choices because the numbers were less for the previous boxes. Thus, there were 504 choices for this case. The second case was when the fourth box was filled with 2, 4, 6 , or 8 . This box had four choices: 2, 4, 6 or 8 . The first box had 8 choices; those were the numbers besides " 0 " and the number in the fourth box. There were only 7 choices for the second box because the numbers that have been put in the first box might not be repeated. The third box had 6 choices because the numbers were less one for the second box. So we can say that there were 1.344 choices for this second case. From both cases there were found $504+1.344=1.848$ licensed plates that can be made.

\begin{tabular}{|l|l|l|l|l|l|l|l|}
\hline 9 & 8 & 7 & 1 & 8 & 7 & 6 & 4 \\
\hline
\end{tabular}

Figure 5. The solution from S2 (Case 1 and 2)

This research revealed that $\mathrm{S} 2$ did not enclose the alphabet part when he arranged the licensed plates because he had considered that to form the even numbers; the alphabet part might be ignored. It can be stated that $\mathrm{S} 2$ has not been able to change the licensed plate problems as he was supposed to be. Student thought 5 numbers to form the even numbers, $0,2,4$, 6,8 so that $\mathrm{S} 2$ was considered to have an ability to correlate the concept of even number definition. Student was able to determine that the box filled first was the fourth box. Student also divided the arrangement of licensed plates into two cases based on the choices of numbers which formed even number. The first case was by considering number " 0 " only and the second one was by considering number beside number " 0 " $(2,4,6,8)$. However, S2 only focused on the fact that he might not repeat the number so that the choices were less one by one for the next box. Whereas, in fact it can be seen on the second choices there should be 8 choices for the second box because the numbers that could be put in was numbers not in the first and second box. So it can be statedthat S2 has not totally been able to determine the numbers that can be set in each box.

\section{Relational understanding in solving the problems based on academic achievement}

The understanding of the concept to a student refers to the relational understanding according to Beswick, 2005; Hodkinson, 2005; Mousley, 2004; Richland, Stigler, \& Holyoak, 2012 defined as correlating something with another correctly and be aware on the 
ongoing process. Relational understanding is a rich and connected network of concepts that produces the conceptual knowledge in which students can understand the rare-step in doing mathematical problems (Olivia \& Pinta, 2013). That relational understanding is very useful in learning mathematics. The further indicators of relational understanding in solving the problems of combinatorial is explained in the Table 1.

Table 1. Indicators of Relational Understanding in Solving Problems

\begin{tabular}{|c|c|}
\hline Indicator & Descriptions \\
\hline $\begin{array}{l}\text { Correlating } \\
\text { various kind of } \\
\text { mathematics } \\
\text { concent }\end{array}$ & $\begin{array}{l}\text { Student was able to correlate } \\
\text { the concept of the definition of } \\
\text { even numbers }\end{array}$ \\
\hline $\begin{array}{l}\text { Applying the } \\
\text { concept in } \\
\text { various forms } \\
\text { of mathematics }\end{array}$ & $\begin{array}{l}\text { Student was able to change the } \\
\text { problems of licensed plate into } \\
\text { four boxes for numbers and two } \\
\text { boxes for alphabet }\end{array}$ \\
\hline \multirow{4}{*}{$\begin{array}{l}\text { Classifying the } \\
\text { objects based } \\
\text { on the } \\
\text { fulfillment of } \\
\text { the } \\
\text { requirements } \\
\text { that form the } \\
\text { concept }\end{array}$} & $\begin{array}{l}\text { a. Student was able to } \\
\text { determine that correct } \\
\text { counting rules to solve the } \\
\text { problems based on what he } \\
\text { knows and what is being } \\
\text { asked }\end{array}$ \\
\hline & $\begin{array}{l}\text { b. Student was able to put the } \\
\text { even numbers for the last } \\
\text { box firstly }\end{array}$ \\
\hline & $\begin{array}{l}\text { c. Student was able to } \\
\text { separate the solution into } \\
\text { two case (case "0" and } \\
\text { except "0) }\end{array}$ \\
\hline & $\begin{array}{l}\text { d. Student was able to } \\
\text { determine the numbers that } \\
\text { can be chosen for first, } \\
\text { second and third boxes for } \\
\text { number }\end{array}$ \\
\hline
\end{tabular}

Relational understanding has some advantages in learning mathematics. Skemp (2006) stated at least four advantages in relational mathematics: (1) Relational mathematics which is more adaptable for new task or problems; (2) Relational mathematics which is easier to remember; (3) Relational knowledge that can be effective as a goal in itself, and (4) relational schemas are organic in quality.
The description of the indicators of student's relational understanding in solving the problems is shown in Table 2 . Based on the result of the test and the interview, it has been found that both $\mathrm{S} 1$ and S2 only have completed one indicator of instrumental understanding that is correlating various kinds of mathematics concept. They were able to correlate the concept of even number. It is also known that both $\mathrm{S} 1$ and $\mathrm{S} 2$ have not completed indicator of applying the concept in various forms of mathematics representatives. They were not able to change the problems of licensed plate into four boxes for numbers and two boxes for alphabet. They only made four boxes for numbers without two boxes for alphabet. They only considered the box of numbers because the problem question led to even number.

The result of this research showed some interesting findings to discuss further. First, indicators related to each other. Because the subject has not been able to change the problem of the licensed plate into four boxes for numbers and two boxes for alphabets, the subject also lacked of ability to determine the numbers that can be set in each box. It means that to solve the problem the students must have a deep comprehension about mathematical concepts or procedurals. It is in line with argument that mathematical problem solving is a complex cognitive activity (Zhu, 2007). Second, by having equal relational understanding, both subjects, showed a different process in solving the problems. S2 student was able to give the more accurate process in solving problem compared to S1. He was also able to divide the arrangement of licensed plates into two cases based on the choices of numbers that would form the even numbers, by considering number " 0 " only and other numbers rather than " 0 " $(2,4,6,8)$. The process in solving problem made by the $\mathrm{S} 2$ student was likely similar to the accurate process in solving problems. 
Table 2. Description of Student's Relational Understanding in Solving the Problems

\begin{tabular}{|c|c|c|c|}
\hline $\begin{array}{l}\text { The Steps } \\
\text { in Solving } \\
\text { Problems }\end{array}$ & $\begin{array}{c}\text { Indicator of } \\
\text { Relational } \\
\text { Understanding }\end{array}$ & S1 & S2 \\
\hline $\begin{array}{l}\text { Understan } \\
\text { ding the } \\
\text { problems } \\
\text { and } \\
\text { making a } \\
\text { plan }\end{array}$ & $\begin{array}{l}\text { Classifying the } \\
\text { objects based on } \\
\text { the fulfillment of } \\
\text { the requirements } \\
\text { that form the } \\
\text { concept }\end{array}$ & $\begin{array}{l}\text { Students was able to determine } \\
\text { the correct counting rules to solve } \\
\text { the problems based on what she } \\
\text { knew and what was being asked }\end{array}$ & $\begin{array}{l}\text { Students was able to determine the } \\
\text { correct counting rules to solve the } \\
\text { problems based on what he knew and } \\
\text { what was being asked }\end{array}$ \\
\hline \multirow[t]{3}{*}{$\begin{array}{l}\text { Applying a } \\
\text { plan }\end{array}$} & $\begin{array}{l}\text { Applying the } \\
\text { concept in various } \\
\text { forms of } \\
\text { mathematics } \\
\text { representatives }\end{array}$ & $\begin{array}{l}\text { Student was not able to change } \\
\text { the problems of licensed plate into } \\
\text { four boxes for numbers and two } \\
\text { boxes for alphabet }\end{array}$ & $\begin{array}{l}\text { Student was not able to change the } \\
\text { problems of licensed plate into four } \\
\text { boxes for numbers and two boxes for } \\
\text { alphabet }\end{array}$ \\
\hline & $\begin{array}{l}\text { Correlating } \\
\text { various kinds of } \\
\text { mathematics } \\
\text { concept }\end{array}$ & $\begin{array}{l}\text { Student was able to correlate the } \\
\text { concept of even numbers } \\
\text { definition }\end{array}$ & $\begin{array}{l}\text { Student was able to correlate the } \\
\text { concept of even numbers definition }\end{array}$ \\
\hline & $\begin{array}{l}\text { Classifying the } \\
\text { objects based on } \\
\text { the fulfillment of } \\
\text { the requirements } \\
\text { that form the } \\
\text { concept }\end{array}$ & $\begin{array}{l}\text { a. Student was able to put the } \\
\text { even numbers for the last box } \\
\text { firstly } \\
\text { b. Student was able to separate } \\
\text { the solution into two cases } \\
\text { (case "0" and except "0") } \\
\text { c. Student was not able to } \\
\text { determine the numbers that } \\
\text { could be chosen for first, } \\
\text { second and third boxes for } \\
\text { number }\end{array}$ & $\begin{array}{l}\text { a. Student was able to put the even } \\
\text { numbers for the last box firstly } \\
\text { b. Student was not able to separate } \\
\text { the solution into two cases (case } \\
\text { " } 0 \text { " and except "0) } \\
\text { c. Student was not able to determine } \\
\text { the numbers that could be chosen } \\
\text { for first, second and third boxes } \\
\text { for number }\end{array}$ \\
\hline
\end{tabular}

\section{CONCLUSIONS AND RECOMMENDATIONS}

From the above description, it can be concluded that the ability of relational understanding between high and medium academic achievement students is similar. Both of them were capable of correlating various kinds of mathematics concept but not capable of classifying the objects based on the fulfilment of the requirements that formed the concept and applied the concept in various forms of mathematics representatives. Although there was still a light difference in the process of solving problem between both of them. The difference is that the high-academic achievement student was capable of differentiating the steps of arranging the licenced plates into two cases. In contrast, the medium-academic achievement student was not. This showed that they had the similar level of relational understanding.
They just shared their different way to solve the problems of combinatorica. For further research, it is supposed not only study about relational understanding but also about instrumental understanding. For further research can compare relational understanding between FI and FD students.

\section{REFERENCES}

Amato, S. A. (2004). Improving Student Teachers' Attitudes to Mathematics. International Group for the Psychology of Mathematics Education.

Anwar, R. B., Yuwono, I., \& As' ari, A. R. (2016). Mathematical Representation by Students in Building Relational Understanding on Concepts of Area and Perimeter of Rectangle. Educational Research and Reviews, 11(21), 2002-2008. 
Ayllón, M. F., Gómez, I. A., \& BallestaClaver, J. (2016). Mathematical Thinking and Creativity through Mathematical Problem Posing and Solving. Journal of Educational Psychology-Propósitos Representaciones, 4(1), 195-218.

Barmby, P., Harries, T., Higgins, S., \& Suggate, J. (2007). How can we assess mathematical understanding. In Proceedings of the 31st Conference of the International Group for the Psychology of Mathematics Education (Vol. 2, pp. 41-48). ERIC.

Beswick, K. (2005). Preservice Teachers' Understandings of Relational and Instrumental Understanding. International Group for the Psychology of Mathematics Education, 2, 161-168.

Boaler, J. (2008). Promoting 'relational equity'and high mathematics achievement through an innovative mixed-ability approach. British Educational Research Journal, 34(2), 167-194.

Creswell, J. W., \& Creswell, J. D. (2017). Research design: Qualitative, quantitative, and mixed methods approaches. Sage publications.

Draper, R. J. (2002). School mathematics reform, constructivism, and literacy: A case for literacy instruction in the reform-oriented math classroom. Journal of Adolescent \& Adult Literacy, 45(6), 520-529.

Ferrini-Mundy, J. (2000). Principles and standards for school mathematics: A guide for mathematicians. Notices of the American Mathematical Society, 47(8).

Friel, S., Rachlin, S., Doyle, D., Nygard, C., Pugalee, D., \& Ellis, M. (2001). Navigating through algebra in grades 6-8. Principles and standards for school mathematics navigations series. Reston, VA: National Council of Teachers of Mathematics.

Geary, D. C. (2004). Mathematics and learning disabilities. Journal of Learning Disabilities, 37(1), 4-15.

Graham, K. J. (2001). Principles and standards for school mathematics and teacher education: Preparing and empowering teachers. School Science and Mathematics, 101(6), 319-327.

Hebert, L. (2001). A comparison of learning outcomes for dualenrollment mathematics students taught by high school teachers versus college faculty. Community College Review, 29(3), 22-38.

Hodkinson, P. (2005). Learning as cultural and relational: Moving past some troubling dualisms. Cambridge Journal of Education, 35(1), 107119.

Indonesia, P. P. R. (2005). Standar Nasional Pendidikan. Jakarta. Departemen Pendidikan Nasional.

Jordan, N. C., \& Levine, S. C. (2009). Socioeconomic variation, number competence, and mathematics learning difficulties in young children. Developmental Disabilities Research Reviews, 15(1), 60-68.

Knuth, E. J., Alibali, M. W., McNeil, N. M., Weinberg, A., \& Stephens, A. C. (2005). Middle school students' understanding of core algebraic concepts: Equivalence \& variable. Zentralblatt Für Didaktik Der Mathematik, 37(1), 68-76.

Lusiana, R. (2017). Analisis kesalahan Mahasiswa dalam memecahkan masalah pada materi himpunan 
ditinjau dari gaya kognitif. Jurnal Penelitian Dan Pembelajaran Matematika, 10(1).

McNeil, N. M., Grandau, L., Knuth, E. J., Alibali, M. W., Stephens, A. C., Hattikudur, S., \& Krill, D. E. (2006). Middle-school students' understanding of the equal sign: The books they read can't help. Cognition and Instruction, 24(3), 367-385.

Morgan, P. L., Farkas, G., \& Wu, Q. (2009). Five-year growth trajectories of kindergarten children with learning difficulties in mathematics. Journal of Learning Disabilities, 42(4), 306-321.

Mousley, J. (2004). An Aspect of Mathematical Understanding: The Notion of" Connected Knowing". International Group for the Psychology of Mathematics Education.

Nasional, D. P. (2006). Peraturan Menteri Pendidikan Nasional Republik Indonesia Nomor 22 Tahun 2006 tentang Standar Isi untuk Satuan Pendidikan Dasar dan Menengah. Jakarta: Departemen Pendidikan Nasional.

Olivia, C., \& Pinta, D. (2013). Meiliasari.(2013). Mengembangkan pemahaman relasional siswa mengenai luas bangun datar segiempat dengan pendekatan PMRI. In Seminar Nasional Matematika dan Pendidikan Matematika (pp. 125-132).

Pendidikan, B. S. N. (2007). Standar Proses untuk Satuan Pendidikan Dasar dan Menengah. Badan Standar Nasional Pendidikan.

Richland, L. E., Stigler, J. W., \& Holyoak, K. J. (2012). Teaching the conceptual structure of mathematics.
Educational Psychologist, 47(3), 189-203.

Sahin, Z., Yenmez, A. A., \& Erbas, A. K. (2015). Relational Understanding of the Derivative Concept through Mathematical Modeling: A Case Study. Eurasia Journal of Mathematics, Science \& Technology Education, 11(1).

Skemp, R. R. (2006). Relational understanding and instrumental understanding. Mathematics Teaching in the Middle School, 12(2), 88-95.

Stylianides, A. J., \& Stylianides, G. J. (2007). Learning mathematics with understanding: A critical consideration of the learning principle in the principles and standards for school mathematics. The Mathematics Enthusiast, 4(1), 103-114.

Suherman, E. (2003). Strategi pembelajaran matematika kontemporer. Bandung: Jica.

Surya, E., \& Syahputra, E. (2017). Improving High-Level Thinking Skills by Development of Learning PBL Approach on the Learning Mathematics for Senior High School Students. International Education Studies, 10(8), 12-20.

Widjajanti, D. B. (2009). Kemampuan pemecahan masalah matematis mahasiswa calon guru matematika: apa dan bagaimana mengembangkannya. In Seminar Nasional Matematika dan Pendidikan Matematika (Vol. 5). 